\title{
Progesterone metabolism during embryonic diapause in the tammar wallaby, Macropus eugenii*
}

\author{
C. Sernia†, L. Hinds and C. H. Tyndale-Biscoe \\ CSIRO, Division of Wildlife Research, P.O. Box 84, Lyneham, A.C.T. 2602, Australia
}

Summary. Metabolic clearance rate (MCR), production rate (PR) and plasma protein-binding of progesterone were measured during embryonic diapause and after ovariectomy in the tammar wallaby. The effect of ovine prolactin and LH on the secretion of progesterone by the quiescent corpus luteum in vitro was also examined.

During embryonic diapause, a low plasma progesterone concentration of $196 \pm 24$ (s.e.m.) $\mathrm{pg} / \mathrm{ml}(n=7)$ was associated with a low PR of $20.2 \pm 1.4$ $\mathrm{ng} / \mathrm{kg} / \mathrm{min}$ and a high MCR of $111.0 \pm 7.6 \mathrm{ml} / \mathrm{kg} / \mathrm{min}$. Similar values were obtained for the 4 animals ovariectomized 9 or 12 months previously (plasma progesterone $=156 \pm 14 \mathrm{pg} / \mathrm{ml} ; \quad M C R=147 \pm 16 \mathrm{ml} / \mathrm{kg} / \mathrm{min} ; \quad P R=20.4 \pm 2 \cdot 2$ $\mathrm{ng} / \mathrm{kg} / \mathrm{min}$ ) although plasma progesterone concentration was decreased by about $50 \%$ within 14 days of ovariectomy. An increased adrenal cortical secretion of progesterone in long-term ovariectomized tammars is suggested.

Progesterone was bound by plasma protein. The association constant at $20^{\circ} \mathrm{C}$ was similar for intact $\left(2.31 \times 10^{8} \mathrm{M}^{-1}\right)$ and ovariectomized $\left(2.27 \times 10^{8} \mathrm{M}^{-1}\right)$ tammars while the concentration of binding sites was significantly lower in ovariectomized $\left(1.41 \times 10^{-7} \mathrm{M}\right)$ than in intact $\left(2.28 \times 10^{-7} \mathrm{M}\right)$ tammars. Cortisol and $17 \alpha$-hydroxyprogesterone competed with progesterone for binding sites while $20 \alpha$-dihydroprogesterone, oestradiol-17 $\beta$ and testerone did not.

Progesterone was secreted by quiescent corpora lutea in vitro but neither LH nor prolactin changed its rate of secretion.

\section{Introduction}

The female tammar wallaby (Macropus eugenii) mates and usually conceives within a day of parturition, as do most other members of the Family Macropodidae (see Tyndale-Biscoe, 1973; Tyndale-Biscoe, Hearn \& Renfree, 1974). The new pregnancy does not proceed to term but is arrested, together with the corpus luteum (CL), at the blastocyst stage and normally remains so until the next summer solstice, some 11 months later (Berger, 1966). This condition, termed quiescence, may be terminated in the early part of the annual cycle by removal or loss of the sucking pouch young (Renfree \& Tyndale-Biscoe, 1973), or by the suppression of prolactin secretion with bromocriptine (C. H. Tyndale-Biscoe \& L. Hinds, unpublished observations). Development also resumes after hypophysectomy (Hearn, 1973), unless followed by prolactin treatment when quiescence continues for the duration of treatment (Tyndale-Biscoe \& Hawkins, 1977). These experiments provide evidence for an inhibitory role of prolactin in embryonic diapause and the recent finding of luteal prolactin-specific binding sites (Sernia \& Tyndale-

* Reprint requests to $\mathrm{Dr}$ C. H. Tyndale-Biscoe.

† Present address: Department of Physiology and Pharmacology, University of Queensland, St Lucia, Queensland, 4067, Australia. 
Biscoe, 1979) indicates that the CL is probably a major target tissue. Unlike the luteotrophic function of prolactin in the rat, ferret and sheep (Donovan, 1963; Denamur, Martinet \& Short, 1973; Ford \& Yoshinaga, 1975), in the tammar wallaby prolactin may suppress progesterone secretion by the $\mathrm{CL}$ and in this way prevent the induction of uterine conditions required for continued growth of the conceptus (Renfree \& Tyndale-Biscoe, 1973).

However, relatively little is known of the steroidogenic function of the CL in this species. Progesterone is synthesized in vitro and has been measured in extracts of quiescent and reactivated CL (Renfree \& Heap, 1977; Renfree, Green \& Young, 1979). Plasma concentrations of progesterone during the oestrous cycle and gestation have been reported (Lemon, 1972; Renfree \& Heap, 1977), but there is no detailed information on progesterone metabolism in vivo during various reproductive states and, in particular, during embryonic diapause. The steroidogenic function of the tammar CL in vivo was therefore examined by measuring production rates and metabolic clearance rates of progesterone during embryonic diapause and after ovariectomy. The effect of prolactin on the release of progesterone by CL in vitro was also investigated.

\section{Materials and Methods}

Tammar wallabies $(3 \cdot 8-5 \cdot 6 \mathrm{~kg})$ were obtained from a captive colony housed in outdoor grassed pens with access to an oat/lucerne feed mix.

\section{Production and metabolic clearance rate measurements}

The production rate (PR) and metabolic clearance rate (MCR) of progesterone were measured by the constant rate infusion method of Tait \& Burstein (1964). The animals were anaesthetized with sodium amytal (Surital: Parke-Davies) and a catheter was inserted into the exterior jugular vein of each and exteriorized at the back of the neck, immediately above the scapulae. After one or more days of post-operative recovery a second catheter was inserted into a tail vein and a blood sample was taken $(8 \mathrm{ml})$; the catheter was secured with tape and left in position. The tammars were accommodated in hessian bags with suitable slits for the tail and jugular catheters. Within the darkness of the bag, and in a quiet environment, these normally excitable animals became relatively docile and further restraint was unnecessary.

After a short period of acclimatization, $10 \mu \mathrm{Ci}\left[{ }^{3} \mathrm{H}\right]$ progesterone in $3 \mathrm{ml} \mathrm{10 \%}(\mathrm{v} / \mathrm{v})$ ethanolic saline were quickly injected via the jugular catheter and 10 min later a constant infusion of 2-3 $\mu \mathrm{Ci} / \mathrm{h} / \mathrm{kg}$ was begun using a motor-driven pump (B. Braun, West Germany). The specific activity of the plasma reached a steady state within $2 \mathrm{~h}$ of the start of infusion and thereafter 3 blood samples $(6-10 \mathrm{ml})$ were collected via the tail vein at 20 -min intervals. Plasma was separated from erythrocytes by centrifugation at room temperature and plasma progesterone. was extracted by $3 \times 5$ volumes of redistilled hexane. The extract was evaporated to dryness by a stream of air and the residue was redissolved in $3 \mathrm{ml}$ hexane. The equivalent of $1 \mathrm{ml}$ plasma was assayed for progesterone and $5 \mu \mathrm{g}$ authentic radioinert progesterone were added to the remaining extract. The $\left[{ }^{3} \mathrm{H}\right]$ progesterone and the authentic carrier were purified by thin-layer chromatography using a developing system of cyclohexane/iso-octane/chloroform (22/25/30 by vol.) and the recovered radioactivity was measured by liquid scintillation counting. Procedural losses of $30.0 \pm 1.8 \%$ (s.e.m.) $(n=5)$ were calculated from plasma samples containing known amounts of $\left[{ }^{3} \mathrm{H}\right]$ progesterone.

\section{Binding of progesterone to plasma protein}

Endogenous steroids were removed from plasma by treatment with charcoal (Norit A; $50 \mathrm{mg} / \mathrm{ml})$ for $1.5 \mathrm{~h}$ at room temperature. To a sample $(100 \mu \mathrm{l})$ of this plasma was added 
$100 \mu \mathrm{l}$ sodium phosphate buffer $(10 \mathrm{~mm}, \mathrm{pH} 7.6)$ containing 70000 d.p.m. $\left[{ }^{3} \mathrm{H}\right]$ progesterone and radioinert progesterone, 17 $\alpha$-hydroxyprogesterone, 20 $\alpha$-dihydroprogesterone, cortisol, oestradiol-17 $\beta$ or testosterone (Sigma). After incubation for $12 \mathrm{~h}$ at $2^{\circ} \mathrm{C}$, the sample was transferred to a $0.7 \times 18 \mathrm{~cm}$ column of Sephadex G-25F (Pharmacia) and eluted at $2^{\circ} \mathrm{C}$ with 10 mM-phosphate buffer ( $\mathrm{pH} \mathrm{7.6)}$. Fractions of $0.3 \mathrm{ml}$ were collected and the radioactivity was measured. Data for the estimation of association constant and concentration of progesterone binding sites were obtained by the microcolumn method of Ginsburg, Greenstein, MacLusky, Morris \& Thomas (1974). Steroid-free plasma was diluted 1:14 with phosphate buffer (10 mM, $\mathrm{pH} 7.6)$ containing $\left[{ }^{3} \mathrm{H}\right]$ progesterone $(70000$ d.p.m.) and various concentrations of nonradioactive progesterone to a final volume of $250 \mu \mathrm{l}$. After a $12 \mathrm{~h}$ incubation at $2^{\circ} \mathrm{C}$, protein-bound and free progesterone were separated on microcolumns of Sephadex LH-20 at $2{ }^{\circ} \mathrm{C}$ and the association constant and binding site concentration were estimated from a Scatchard plot of the data (Scatchard, 1949). All data were corrected for non-specific binding, defined as the radioactivity bound in the presence of excess $\left(5 \times 10^{-7} \mathrm{M}\right)$ progesterone. The concentration of protein in undiluted plasma was measured by the method of Lowry, Rosebrough, Farr \& Randall (1951).

\section{CL incubations}

Quiescent corpora lutea were obtained from lactating tammars with pouch young $(6 \cdot 3-73 \cdot 9$ g) during late April-early May. All animals were treated with a single i.m. injection of $5 \mathrm{mg}$ bromocriptine (CB154: Sandoz, Australia)/kg and the pouch young were removed approximately $16 \mathrm{~h}$ before the parent was killed by stunning and cervical dislocation. A blood sample for later assay of progesterone was taken by cardiac puncture immediately after death. In 3 separate experiments, the single CL from each tammar wallaby was bisected and each half allocated according to a balanced incomplete block design (John \& Quenouille, 1977) to a control incubation in buffer alone or a treatment incubation in which the medium contained ovine prolactin $(2 \mu \mathrm{g} / \mathrm{ml}$ : NIH-S10) or ovine LH (2 $\mu \mathrm{g} / \mathrm{ml}: \mathrm{NIH}-\mathrm{S} 19)$. After incubation for $4 \mathrm{~h}$ at $35^{\circ} \mathrm{C}$ (the average body temperature of the tammar) in an atmosphere of $95 \% \mathrm{O}_{2}-5 \% \mathrm{CO}_{2}$, the CL tissue was removed and the progesterone released into the medium was extracted with $2 \times 10 \mathrm{ml}$ hexane and stored for later radioimmunoassay. The incubation medium in each vial consisted of $4 \mathrm{ml}$ Krebs-Henseleit buffer at $\mathrm{pH} 7.4(118 \mathrm{mM}-\mathrm{NaCl}, 4.7 \mathrm{mM}-\mathrm{KCl}, 1.4$ mM- $\mathrm{MgCl}_{2} \cdot 6 \mathrm{H}_{2} \mathrm{O}, 2 \cdot 5 \mathrm{~mm}-\mathrm{CaCl}_{2}, 1 \cdot 2 \mathrm{~mm}-\mathrm{KH}_{2} \mathrm{PO}_{4}, 25 \mathrm{~mm}-\mathrm{NaHCO}_{3}, 10 \mathrm{~mm}$-glucose).

\section{Progesterone assay}

Antiserum to progesterone (Lot S230) was supplied by Dr R. I. Cox, CSIRO, Division of Animal Production Prospect, New South Wales. Antibodies were raised in sheep to progesterone-11-hemisuccinate-BSA. Cross-reactivity relative to progesterone was $<0 \cdot 3 \%$ for

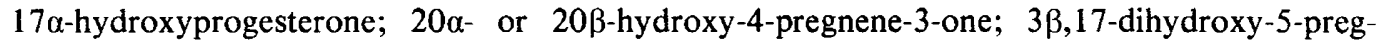
nene-20-one; $5 \beta$-pregnane-3 $\alpha, 20 \beta$-diol; $5 \beta$-pregnane-3 $\alpha, 20 \alpha$-diol; cortisol and corticosterone. Higher cross-reactivity was present with 11-deoxycorticosterone (1.0\%), pregnenolone $(1.6 \%)$, $5 \beta$-pregnane-3,20-dione $(3 \cdot 5 \%)$ and $11 \beta$-hydroxyprogesterone $(6 \cdot 7 \%)$.

The assay procedure was based on that of Abraham, Swerdloff, Tulchinsky \& Odell (1971). Progesterone in plasma or CL incubation media was extracted with $2 \times 10$ volumes of freshly redistilled $n$-hexane. The pooled extract was cooled in solid $\mathrm{CO}_{2}$ /ethanol to solidify the aqueous phase, and the organic phase was then decanted and dried under air at $37^{\circ} \mathrm{C}$. To these dried extracts and to progesterone standards ranging from 10 to $500 \mathrm{pg} /$ tube was added $1.2 \mathrm{ml}$ of assay buffer ( $1.0 \%$ gelatin in $0.2 \mathrm{M}$-phosphate buffer, $\mathrm{pH} 7.0$ ) followed by an equilibration period of $4 \mathrm{~h}$ at room temperature. Duplicate $0.5 \mathrm{ml}$ aliquots were then pipetted into assay tubes and antiserum (1:1000 dilution) and 10000 c.p.m. $\left[1,2,6,7(\mathrm{~N})-{ }^{3} \mathrm{H}\right]$ progesterone (Lot 
1004-110, sp act. $114 \mathrm{Ci} / \mathrm{mmol}$ : New England Nuclear) were added in a $0.2 \mathrm{ml}$ volume, with thorough mixing of contents. After a $14-18 \mathrm{~h}$ incubation at $4^{\circ} \mathrm{C}$ free steroid was removed by charcoal treatment $(0.2 \mathrm{ml}$ of $0.625 \%$ in assay buffer) for $30 \mathrm{~min}$. The charcoal was sedimented by centrifugation $(2500 \mathrm{~g}, 15 \mathrm{~min})$ and $0.5 \mathrm{ml}$ supernatant was added to $10 \mathrm{ml}$ scintillation fluid ( $42 \mathrm{ml}$ Liquifluor and $150 \mathrm{ml}$ dioxan in 1 litre toluene). After a $4 \mathrm{~h}$ extraction period at $4^{\circ} \mathrm{C}$, the radioactivity in these samples was measured in a spectrophotometer (Isocap/300, Searle) at an efficiency of $65 \%$. With this procedure, there was no detectable interference from solvents or extracts of charcoal-treated plasma, provided glassware was rinsed in ethanol and the $\mathrm{n}$-hexane redistilled. Efficiency of the extraction procedure was $85-95 \%$ as determined from the recovery of radioactive progesterone equilibrated with endogenous plasma progesterone. Assay sensitivity, defined as the least measurable amount of progesterone, was $25 \mathrm{pg} / \mathrm{ml}$. Intra- and inter-assay co-efficients of variation of 9.0 and $13.0 \%$ respectively were determined from repeated measures of a single pool of plasma within the same assay $(n=10)$ and in separate assays $(n=29)$. Accuracy was determined by the addition of progesterone to charcoal-treated plasma to a final concentration of $100,200,300$ or $400 \mathrm{pg} / \mathrm{ml}$. The measured concentration was always within $16 \%$ of that expected; a highly significant $\left(r^{2}=0.996, P<0.001\right)$ linear correlation was present.

\section{Statistics}

All data are represented as mean \pm s.e.m. and were analysed by parametric tests except for those in Table 1.

Table 1. Plasma concentration, production rate $(P R)$ and metabolic clearance (MCR) of progesterone in intact (Nos 1-7) and ovariectomized (Nos 8-11) tammar wallabies

\begin{tabular}{|c|c|c|c|c|c|}
\hline \multirow[b]{2}{*}{ Tammar } & \multirow[b]{2}{*}{ Body wt (kg) } & \multicolumn{2}{|c|}{ Progesterone conc. $(\mathrm{pg} / \mathrm{ml})$} & \multirow{2}{*}{$\begin{array}{c}\mathrm{MCR} \\
(\mathrm{ml} / \mathrm{kg} / \mathrm{min})\end{array}$} & \multirow{2}{*}{$\begin{array}{c}\mathrm{PR} \\
(\mathrm{ng} / \mathrm{kg} / \mathrm{min})\end{array}$} \\
\hline & & Pre-infusion & Steady state & & \\
\hline \multicolumn{6}{|l|}{ Intact } \\
\hline 1 & 4.44 & 103 & 157 & 100 & $15 \cdot 7$ \\
\hline 2 & $3 \cdot 92$ & 119 & 187 & 126 & $23 \cdot 6$ \\
\hline 3 & 4.42 & 97 & 167 & 124 & $20 \cdot 7$ \\
\hline 4 & 4.04 & 122 & 172 & 121 & $20 \cdot 8$ \\
\hline 5 & 4.93 & 461 & 331 & 70 & $23 \cdot 2$ \\
\hline 6 & $4 \cdot 24$ & 157 & 132 & 109 & 14.4 \\
\hline 7 & $4 \cdot 42$ & 140 & 181 & 124 & $23 \cdot 1$ \\
\hline Mean \pm s.e.m. & $4 \cdot 34 \pm 0 \cdot 12$ & $171 \pm 49$ & $196 \pm 24$ & $111 \pm 7 \cdot 6$ & $20 \cdot 2 \pm 1 \cdot 4$ \\
\hline \multicolumn{6}{|l|}{ Ovariectomized } \\
\hline $8^{*}$ & 4.68 & 337 & 128 & 153 & $19 \cdot 6$ \\
\hline $9 \dagger$ & 4.06 & 131 & 147 & 179 & $26 \cdot 3$ \\
\hline $10^{*}$ & $4 \cdot 40$ & 81 & 102 & 155 & $15 \cdot 8$ \\
\hline $11 \dagger$ & 4.05 & 149 & 193 & 102 & $19 \cdot 7$ \\
\hline Mean \pm s.e.m. & $4.30 \pm 0.15$ & $175 \pm 56$ & $156 \pm 14$ & $147 \pm 16$ & $20.4 \pm 2 \cdot 2$ \\
\hline
\end{tabular}

\section{Results}

\section{Production and metabolic clearance rates}

These values were measured in 7 post-lactational females with quiescent corpora lutea and in 4 females ovariectomized 9 or 24 months previously. All measurements were made in November, approximately 2 months before the annual breeding season. 
The concentration of progesterone during the pre-infusion period was comparable to that during steady-state conditions $(P>0.05$, Wilcoxon's matched pairs test), although a greater variation was present in the pre-infusion samples (Table 1). In steady-state conditions, the plasma concentration and MCR of progesterone in ovariectomized tammars were surprisingly similar to those of intact tammars; the production rate for both groups was identical. There was some suggestion of an inverse relationship between MCR and plasma progesterone concentration but non-parametric tests indicated a poor correlation (Spearman's $r=0.58$, $P<0 \cdot 1)$.

In a further 5 tammar wallabies in seasonal quiescence the short-term changes in plasma progesterone concentration following bilateral ovariectomy were measured. The concentration decreased from $206 \pm 8 \mathrm{pg} / \mathrm{ml}$ before surgery to $141 \pm 9$ and $99 \pm 6 \mathrm{pg} / \mathrm{ml}$ at 7 and 14 days after surgery respectively $(P<0.01$, analysis of variance for repeated measures).

\section{Binding to plasma proteins}

Chromatography showed that most of the progesterone was bound to protein (Text-fig. 1a). Incubation in the presence of $1 \times 10^{-7} \mathrm{M}$-radioinert progesterone (data not shown), cortisol or $17 a$-hydroxyprogesterone decreased the protein-bound $\left[{ }^{3} \mathrm{H}\right]$ progesterone by 90,65 and $17 \%$ respectively, while $20 \alpha$-dihydroprogesterone, oestradiol- $17 \beta$ and testosterone were ineffective $(<3 \%)$ in displacing bound $\left[{ }^{3} \mathrm{H}\right]$ progesterone.
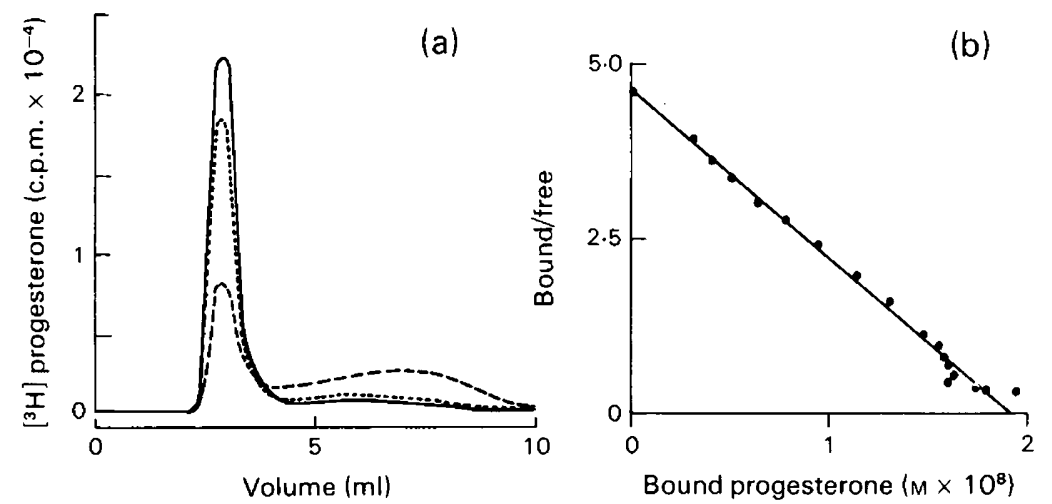

Text-fig. 1. Steroid-binding properties of tammar wallaby plasma. (a) Separation at $2{ }^{\circ} \mathrm{C}$ of protein-bound and unbound $\left[{ }^{3} \mathrm{H}\right]$ progesterone $(-)$ on a column of Sephadex G-25 and displacement by non-radioactive $17 \alpha$-hydroxyprogesterone (.........) and cortisol (---). (b) A Scatchard plot of the binding of progesterone to diluted $(1: 14 \mathrm{v} / \mathrm{v})$ tammar wallaby plasma $\left(K_{\mathrm{a}}=2.43 \times 10^{8} \mathrm{M}^{-1} ; \mathrm{N}=1.91 \times 10^{-8} \mathrm{M}\right)$.

The Scatchard analysis of the binding data is shown in Text-fig. 1(b). Values for the association constant fell in a narrow range (Table 2) with no significant difference between intact and ovariectomized tammars, but there were significantly more binding sites in the intact than in the ovariectomized animals. The plasma protein concentration was also lower in the ovariectomized tammars. A regression analysis of the data from all 11 animals indicated a significant correlation $(r=0.75, P<0.05)$ between protein concentration and progesterone binding sites.

\section{Secretion of progesterone in vitro}

The amounts of progesterone secreted by the luteal tissue in the 3 experiments are shown in Table 3. An analysis of variance of the pooled data indicated that there were no differences 
Table 2. Association constant and concentration of binding sites for the binding of progesterone to plasma proteins of intact (Nos 1-7) and ovariectomized (Nos 8-11) tammar wallabies

\begin{tabular}{|c|c|c|c|}
\hline Tammar & $\begin{array}{c}\text { Protein conc. } \\
\text { (g/100 ml plasma) }\end{array}$ & $\begin{array}{l}\text { Association constant } \\
\qquad\left(\times 10^{-8} \mathrm{M}^{-1}\right)\end{array}$ & $\begin{array}{l}\text { Binding site conc. } \\
\qquad\left(\times 10^{7} \mathrm{M}\right)\end{array}$ \\
\hline \multicolumn{4}{|l|}{ Intact } \\
\hline 1 & $6 \cdot 69$ & $2 \cdot 33$ & 1.76 \\
\hline 2 & 6.69 & $2 \cdot 35$ & $2 \cdot 52$ \\
\hline 3 & $6 \cdot 77$ & $2 \cdot 60$ & $2 \cdot 30$ \\
\hline 4 & $6 \cdot 16$ & $2 \cdot 36$ & 1.84 \\
\hline 5 & $7 \cdot 11$ & $2 \cdot 02$ & $2 \cdot 05$ \\
\hline 6 & $6 \cdot 80$ & $2 \cdot 12$ & $2 \cdot 67$ \\
\hline 7 & $7 \cdot 26$ & $2 \cdot 43$ & $2 \cdot 86$ \\
\hline Mean \pm s.e.m. & $6.78 \pm 0.13^{*}$ & $2.31 \pm 0.07$ & $2 \cdot 28 \pm 0.16^{* *}$ \\
\hline \multicolumn{4}{|l|}{ Ovariectomized } \\
\hline 8 & 6.98 & $2 \cdot 32$ & 1.78 \\
\hline 9 & 5.40 & $2 \cdot 13$ & 1.49 \\
\hline 10 & $5 \cdot 51$ & $2 \cdot 40$ & 0.95 \\
\hline 11 & $5 \cdot 84$ & $2 \cdot 23$ & 1.43 \\
\hline Mean \pm s.e.m. & $5.93 \pm 0.36^{*}$ & $2.27 \pm 0.06$ & $1.41 \pm 0.17^{* *}$ \\
\hline
\end{tabular}

Table 3. Effect of prolactin and $\mathrm{LH}$ on progesterone release in vitro by luteal tissue of tammar wallabies in quiescence*

\begin{tabular}{|c|c|c|c|c|c|c|c|}
\hline \multirow[b]{2}{*}{ Exp. } & \multirow[b]{2}{*}{$\begin{array}{c}\text { No. of } \\
\text { animals }\end{array}$} & \multirow[b]{2}{*}{$\begin{array}{c}\text { Wt of } \\
\text { CL (mg) }\end{array}$} & \multirow{2}{*}{$\begin{array}{c}\text { Plasma } \\
\text { progesterone } \\
(\mathrm{pg} / \mathrm{ml})\end{array}$} & \multirow[b]{2}{*}{$\begin{array}{c}\text { Replicates/ } \\
\text { treatment }\end{array}$} & \multicolumn{3}{|c|}{ Progesterone secretion $(\mathrm{ng} / \mathrm{mg} / 4 \mathrm{~h})$} \\
\hline & & & & & Control & $\begin{array}{l}\text { Prolactin } \\
(2 \mu \mathrm{g} / \mathrm{ml})\end{array}$ & $\begin{array}{c}\mathrm{LH} \\
(2 \mu \mathrm{g} / \mathrm{ml})\end{array}$ \\
\hline A (May) & 6 & $11.9 \pm 1.1$ & $186 \pm 21$ & 4 & $41.3 \pm 0.8$ & $27 \cdot 1 \pm 3 \cdot 1$ & $42.2 \pm 0.8$ \\
\hline B (May) & 6 & $10.9 \pm 0.6$ & $188 \pm 25$ & 4 & $20 \cdot 6 \pm 1.3$ & $49.8 \pm 13.6$ & $41.0 \pm 12.7$ \\
\hline C (July) & 6 & $8.4 \pm 0.5 \dagger$ & $163 \pm 20$ & 4 & $46 \cdot 2 \pm 6 \cdot 0$ & $51.5 \pm 6 \cdot 6$ & $42.7 \pm 9.2$ \\
\hline Overall mean & & & & & $36 \cdot 1 \pm 3 \cdot 8$ & $42 \cdot 8 \pm 5 \cdot 7$ & $42.0 \pm 4.7$ \\
\hline
\end{tabular}

Values are mean \pm s.e.m.

* Endogenous prolactin secretion was suppressed by an injection of bromocriptine $(5 \mathrm{mg} / \mathrm{kg}$, i.m.) and removal of sucking pouch young $16 \mathrm{~h}$ before the experiment.

$\dagger$ Significantly different from values in Exps $\mathrm{A}$ and $\mathrm{B}(P<0.05)$.

between the 3 treatment groups, although there was a difference between the experiments. Progesterone concentration and $\mathrm{CL}$ weight were lower in Exp. C but only the latter was significantly so. The correlation between plasma progesterone and weight of corpus luteum in all 18 animals was poor $(r=0 \cdot 29, P>0 \cdot 1)$.

Recent corpora albicantia from tammars with quiescent corpora lutea were also harvested and incubated without pituitary hormones in conditions identical to those for the corpus luteum. The progesterone released over a $4 \mathrm{~h}$ period was $7 \cdot 2 \pm 1.3 \mathrm{ng} / \mathrm{mg}$.

\section{Discussion}

Unusually low plasma concentrations of progesterone during the oestrous cycle and pregnancy in the tammar wallaby were first reported by Lemon (1972) who measured the steroid with a

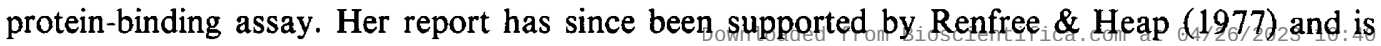


also confirmed in the present investigation in which a sensitive and specific radioimmunoassay was used. Other marsupials investigated so far do not have such low concentrations of progesterone and therefore the low values in the tammar wallaby are unlikely to represent a common feature of marsupials (Cook \& Nalbandov, 1968; Thorburn, Cox \& Shorey, 1971; Gaughwin \& Wells, 1978).

The plasma concentration of progesterone is a function of the rate of production by ovarian and, to a lesser extent, adrenal tissue, and of the rate of clearance by hepatic and other tissues. When compared to several other mammalian species for which data are available (Table 4), it becomes evident that the low plasma concentrations of progesterone in the tammar waliaby are due to a high metabolic clearance rate and a low production rate; the latter being comparable to the rate in ovariectomized eutherian mammals. However, this low secretory activity does not indicate that progesterone is dispensable during embryonic diapause, because ovarian progesterone is important for the long-term viability of dormant blastocysts (Tyndale-Biscoe, 1974). Higher concentrations of this steroid, as after injection, appear to signal the resumption of embryonic development (Renfree \& Tyndale-Biscoe, 1973). The low secretory activity during embryonic diapause may therefore be part of an adaptational mechanism by which progesterone maintains embryonic viability without interrupting diapause.

Table 4. Metabolic clearance rate (MCR) and production rate (PR) of progesterone in various mammalian species

\begin{tabular}{|c|c|c|c|c|}
\hline Species & Reproductive state & $\begin{array}{c}\mathrm{MCR}^{*} \\
(1 / \text { day } / \mathrm{kg})\end{array}$ & $\begin{array}{c}\mathrm{PR}^{*} \\
\text { (mg/day) }\end{array}$ & Reference \\
\hline Rat & $\begin{array}{l}\text { Ovariectomized } \\
\text { Pregnant (Day 15) }\end{array}$ & $\begin{array}{l}103 \\
112\end{array}$ & $\begin{array}{l}0.13 \\
0.46\end{array}$ & Pepe \& Rothchild (1973) \\
\hline Rabbit & Non-pregnant & 230 & 0.5 & Thau \& Lanman (1975) \\
\hline Rhesus monkey & $\begin{array}{l}\text { Follicular phase } \\
\text { Luteal phase }\end{array}$ & $\begin{array}{l}50 \\
55\end{array}$ & $\begin{array}{c}<0.15 \\
1.9\end{array}$ & Thau et al. (1977) \\
\hline Baboon & $\begin{array}{l}\text { Non-pregnant } \\
\text { Pregnant }\end{array}$ & $\begin{array}{l}53 \cdot 1 \\
87 \cdot 3\end{array}$ & $\begin{array}{r}4 \cdot 57 \\
15 \cdot 26\end{array}$ & Albrecht \& Townsley (1976) \\
\hline Man & $\begin{array}{l}\text { Ovariectomized } \\
\text { Pregnant, 3rd trimester }\end{array}$ & $\begin{array}{l}32 \cdot 8 \\
31 \cdot 1\end{array}$ & $\begin{array}{c}0 \cdot 8 \\
210\end{array}$ & $\begin{array}{l}\text { Little et al. (1966) } \\
\text { Lin et al. }(1972)\end{array}$ \\
\hline Tammar wallaby & $\begin{array}{l}\text { Ovariectomized } \\
\text { During embryonic diapause }\end{array}$ & $\begin{array}{l}212 \\
160\end{array}$ & $\begin{array}{l}0.13 \\
0.13\end{array}$ & Present study \\
\hline
\end{tabular}

* Values were calculated from published data for conscious animals. Insufficient details of individual animals prevented the calculation of PR as a function of body weight.

The similar production rates of progesterone in intact and long-term ovariectomized tammars were surprising because, in a separate group, progesterone concentrations had been reduced to $50 \%$ by 14 days after ovariectomy. A compensatory mechanism must presumably be acting in ovariectomized tammars; the eventual increased progesterone production probably being caused by increased secretion from the adrenal cortex.

Corticosteroid-binding and sex-hormone-binding proteins analogous to CBG and SHBG of eutherian mammals have been characterized in numerous marsupial species, including the tammar (Sernia, Bradley \& McDonald, 1979). Marsupial CBG is reported to have a high affinity for both cortisol and progesterone, although the affinity for progesterone was not quantitated. In the present investigation a high-affinity progesterone-binding system was found with a capacity similar to that measured for cortisol by Sernia et al. (1979). Furthermore, bound $\left[{ }^{3} \mathrm{H}\right]$ progesterone was displaced only by cortisol and to a minor extent by $17 \alpha$-hydroxyprogesterone, but not by $20 \alpha$-dihydroprogesterone, testosterone or oestradiol-17 $\beta$. These data suggest that this binding protein has ligand-binding properties like eutherian CBG (see Westphal, 1971) and that progesterone is not bound to a SHBGitike proteims which is innaccordewith 3 the $40: 14 \mathrm{Am}$ 
reported absence of SHBG in the tammar (Sernia et al., 1979). The concentration of progesterone-binding sites of about 300 times that of progesterone during embryonic diapause implies that the plasma steroid is largely in a bound form. Since the protein-bound form is thought to be metabolically inert (Slaunwhite, Lockie, Black \& Sandberg, 1962), the higher MCR of ovariectomized tammars may be due to a significantly lower concentration of CBG (Table 2), probably resulting from the loss of ovarian oestrogens (see Westphal, 1971).

In eutherian mammals, LH stimulates progesterone secretion in vivo and in vitro (Armstrong, 1968) while prolactin, a luteotrophic hormone in several species, does not (Ford \& Yoshinaga, 1975). Similarly, progesterone secretion by the luteinized ovaries of the American opossum (Didelphis) is stimulated by ovine LH but not by FSH or prolactin (Cook \& Nalbandov, 1968). In the present investigation, isolated luteal tissue released about 4 times its reported progesterone content (Renfree et al., 1979) but neither ovine LH nor prolactin had any effect on progesterone secretion. These results cannot be explained simply as non-recognition of ovine hormones by marsupial tissues since both ovine $\mathrm{LH}$ and prolactin bind specifically to marsupial gonadal tissues (Bona-Gallo, Licht, Farmer, Papkoff \& Hawkins, 1978; Sernia \& Tyndale-Biscoe, 1979). The failure of ovine LH to stimulate progesterone secretion in the tammar is, however, consistent with the observation that reactivation occurs after hypophysectomy, i.e. in the complete absence of LH (Hearn, 1973), and further supports the notion that the quiescent corpus luteum is not stimulated by LH.

On the basis of previous reports (Hearn, 1973; Tyndale-Biscoe \& Hawkins, 1977), prolactin was expected to have inhibited progesterone secretion by the tammar CL in vitro. The failure to observe such an effect probably indicates either that repression of steroidogenesis in the quiescent $C L$ is already maximal or that steroidogenesis may not be the primary site of action of prolactin. The role of pituitary hormones in luteal function in the tammar wallaby is being further investigated.

We thank Dr Rob Sutherland for much advice and help with the progesterone assay, Mrs Sue Carpenter for statistical advice, and Mr Roy Coles and Mr Ray Leckie for technical assistance. C.S. was a Research Fellow of the Lalor Foundation.

\section{References}

Abraham, G.E., Swerdloff, R., Tulchinsky, D. \& Odell, W.D. (1971) Radioimmunoassay of plasma progesterone. J. Clin. Endocr. Metab. 32, 619-624.

Albrecht, E.D. \& Townsley, J.D. (1976) Metabolic clearance and production rates of progesterone in non-pregnant and pregnant baboons (Papio papio). Endocrinology 99, 1291-1294.

Armstrong, P.T. (1968) Gonadotropins, ovarian metabolism, and steroid biosynthesis. Recent Prog. Horm. Res. 24, 255-308.

Berger, P.J. (1966) Eleven-month 'embryonic diapause' in a marsupial. Nature, Lond. 211, 435-436.

Bona-Gallo, A.B., Licht, P., Farmer, S.W., Papkoff, H. \& Hawkins, J. (1978) Fractionation and biological actions of pituitary gonadotrophins from a marsupial, the wallaby (Macropus eugenii). Biol. Reprod. 19, 680-687.

Cook, B. \& Nalbandov, A.V. (1968) The effect of some pituitary hormones on progesterone synthesis in vitro by the luteinized ovary of the common opossum (Didelphis marsupialis virginiana). J. Reprod. Fert. 15, 267-275.
Denamur, R., Martinet, J. \& Short, R.V. (1973) Pituitary control of the ovine corpus luteum. J. Endocr. 37, $207-220$

Donovan, B.T. (1963) The effect of pituitary stalk section on luteal function in the ferret. $J$. Endocr. 27, 201-211.

Ford, J.J. \& Yoshinaga, K. (1975) The role of prolactin in the luteotrophic process of lactating rats. Endocrinology 96, 335-339.

Gaughwin, M.D. \& Wells, R.T. (1978) General features of reproduction of the hairy-nosed wombat (Lasiorhinus latifrons) in the Blanche Town region of South Australia. Bull. Aust. Mamm. Soc. 5, 46-47.

Ginsburg, M., Greenstein, B.D., MacLusky, N.J., Morris, I.D. \& Thomas, P.J. (1974) An improved method for the study of high-affinity steroid binding: estradiol binding in brain and pituitary. Steroids 23, 773-792.

Hearn, J.P. (1973) Pituitary inhibition of pregnancy. Nature, Lond. 241,207-208. 
John, J.A. \& Quenouille, M.H. (1977) Experiments: Design and Analysis. Charles Griffin, London.

Lemon, M. (1972) Peripheral plasma progesterone during pregnancy and the oestrous cycle in the tammar wallaby. Macropus eugenii. J. Endocr. 55, 63-71.

Lin, T.J., Lin, S.C., Erlenmeyer, F., Kline, I.T., Underwood, R., Billiar, R.B. \& Little, B. (1972) Progesterone production rates during the third trimester of pregnancy in normal women, diabetic women, and women with abnormal glucose tolerance. J. clin. Endocr. Metab. 34, 287-297.

Little, B., Tait, J.F., Tait, S.A.S. \& Erlenmeyer, F. (1966) The metabolic clearance rates of progesterone in males and ovariectomized females. J. clin. Invest. 45, 901-912.

Lowry, O.H., Rosebrough, N.J., Farr, A.L. \& Randall, R.J. (1951) Protein measurement with the folin phenol reagent. J. biol. Chem. 193, 265-275.

Pepe, G.J. \& Rothchild, I. (1973) Metabolic clearance rate of progesterone: comparison between ovariectomized, pregnant, pseudopregnant and deciduomabearing pseudopregnant rats. Endocrinology 93, 1200-1205.

Renfree, M.B. \& Heap, R.B. (1977) Steroid metabolism by the placenta, corpus luteum and endometrium during pregnancy in the marsupial Macropus eugenii. Theriogenology 8, 164, Abstr.

Renfree, M.B. \& Tyndale-Biscoe, C.H. (1973) Intrauterine development after diapause in the marsupial Macropus eugenii. Devl Biol. 32, 28-40.

Renfree, M.B., Green, S.W. \& Young, I.R. (1979) Growth of the corpus luteum and its progesteronecontent during pregnancy in the tammar wallaby, Macropus eugenii. J. Reprod. Fert. 57, 131-136.

Scatchard, G. (1949) The attraction of proteins for small molecules and ions. Ann. N.Y. Acad. Sci. 51, 660-672.

Sernia, C. \& Tyndale-Biscoe, C.H. (1979) Prolactin receptors in mammary, corpus luteum and other tissues of the tammar wallaby, Macropus eugenii. $J$. Endocr. 83, 79-89.

Sernia, C., Bradley, A.J. \& McDonald, I.R. (1979) High affinity binding of adrenal cortical and gonadal steroids by plasma proteins of Australian marsupials. Gen. comp. Endocr. 32, 496-503.

Slaunwhite, W.R., Lockie, G.N., Black, N. \& Sandberg, A.A. (1962) Inactivity in vivo of transcortin-bound cortisol. Science, N.Y. 135, 1062-1063.

Tait, J.G. \& Burstein, S. (1964) In vivo studies of steroid dynamics in man. In The Hormones, Vol. 5, pp. 441-557. Eds G. Pincus, K. B. Thinman \& E. B. Astwood. Academic Press, New York.

Thau, R.B. \& Lanman, J.T. (1975) Metabolic clearance rates $(M C R)$ and production rates (PR) of plasma progesterone in pregnant and pseudo-pregnant rabbits. Endocrinology 97, 454-457.

Thau, R.B., Lanman, J.T. \& Brinson, A.O. (1977) Metabolic clearance rates, production rates and concentrations of progesterone in pregnant Rhesus monkeys. Biol. Reprod. 16, 678-681.

Thorburn, G.D., Cox, R.I. \& Shorey, C.D. (1971) Ovarian steroid secretion rates in the marsupial Trichosurus vulpecula. J. Reprod. Fert. 24, 139.

Tyndale-Biscoe, C.H. (1973) Life of Marsupials. Edward Arnold, London.

Tyndale-Biscoe, C.H. (1974) Reproduction in marsupials. Aust. Mammal. 1, 175-180.

Tyndale-Biscoe, C.H. \& Hawkins, J. (1977) The corpora lutea of marsupials: aspects of function and control. In Reproduction and Evolution, pp. 245-252. Eds J. H. Calaby \& C. H. Tyndale-Biscoe. Australian Academy of Science, Canberra.

Tyndale-Biscoe, C.H., Hearn, J.P. \& Renfree, M.B. (1974) Control of reproduction in macropodid marsupials. J. Endocr. 63, 587-614.

Westphal, U. (1971) Steroid-Protein Interactions. Springer-Verlag, Berlin.

Received 5 December 1979 